\title{
AKHLAK MAZMUMAH DALAM AL-QURAN
}

\author{
Zulbadri-Sefri Auliya \\ Dosen Fakultas Ushuluddin dan Studi Agama \\ UIN Imam Bonjol Padang
}

\begin{abstract}
Abstrak
Penelitian ini bertujuan untuk membahas akhlak mazmumah dalam Islam. Banyak ditemukan bentuk ungkapan akhlak buruk dalam pergaulan seharihari. Akhlak merupakan perilaku manusia dalam kehidupan sehari-hari yang telah melekat pada diri seseorang. salah dalam tindakan seseorang manusia yang panutannya bersumber dari Al-Qur'an dan Hadis Rasulullah saw. Metode penulisan ini adalah dengan metode Lebrary Riseach. Dalam tulisan ini penulis membahas tentang pengertian akhlak tercela dalam hubungan sesama manusia dengan Allah, hubungan manusia dengan manusia,di antaranya dusta, munafik, melempar tuduhan keji dan menada-adakan kebohongan terhadap orang lain.
\end{abstract}

Kata Kunci: Akhlak, dusta, al-Qur'an.

\section{PENDAHULUAN}

Akhlak pada dasarnya melekat dalam diri seseorang, bersatu dengan perilaku atau perbuatan. Jika perilaku yang melekat itu buruk, maka disebut akhlak yang buruk atau akhlak mazmumah. Sebaliknya, apabila perilaku tersebut baik disebut akhlak mahmudah. ${ }^{1}$ Akhlak buruk yang mesti ditinggalkan di antaranya adalah dusta. Dusta ialah perkataan atau perbuatan yang berbeda dengan kenyataan. ${ }^{2}$ Dan dusta ini merupakan

${ }^{1}$ Syarifah Habibah, Akhlak dan Etika Dalam Islam, Jurnal Pesona Dasar vol. 1 no. 4, oktober 2015, hal 73 - 87

2 Ali bin Muhammad al-Jurjani, AtTa'rifāt , Qahirah ; Dar al-Kitab alMishriy.1991. juz 1 .hal.59. As-Fahany, Mufradat Gharib al-Qur'an, 1:277, Perkataan bermakna tidak benar, bohong, mengkhabarkan sesuatu yang berlainan dengan keadaan sebenarnya. Lafaz bermakna kekal perbuatan buruk yang sangat berbahaya kerana berbahaya kepada

dan sentiasa dalam dusta, pembohong, semakna dengan perkataan dengan bentuk masdar, dan dalam bentuk jama', yang bererti apabila dia mengucapkan suatu perkataan senantiasa dusta( al-Jawāhir, as-sahah fi al-lughah, juz.1 hal.308) Makna al-kidhb menyampaikan kepada orang lain tidak seperti mana yang dikhabarkan kepadanya. 'Ali bin Muhammad al-Jurjani, At-Ta'rifāt, Qahirah ; Dar al-Kitab al-Mishriy.1991. juz 1 .hal.59).atau melakukan sesuatu yang tidak sesuai dengan keyakinannya,(As-Fahany, Mufradat Gharib alQur'an, 1:277) Makna أكذبته Melihat sesuatu perkara itu selalu dengan penuh dusta dan bohong, gurauan atau main-main, ( Ibn Manzhur, lisanu al-'Arab , Beirut, Darul Shadir, t.th, juz1. Hal 704) adalah dusta pada perkataan merupakan dosa yang paling buruk dan keji (Abu hamid Muhammad bin Muhammad al-Ghazaliy, Ihya Ulumu al-dinn, Qahirah: Dar at-Tauzi'wa an-Nasyr alIslamiyah, 2005.hal .482). 
diri sendiri dan orang lain. Namun sangat disayangkan, sebagian dari kaum muslimin menganggap berdusta adalah perkara yang biasa-biasa sahaja, bahkan mereka sering terlibat melakukannya. kebiasaan berdusta dijelaskan firman Allah SWT yang berikut:

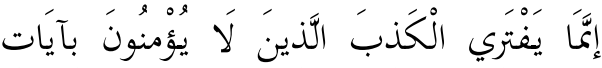

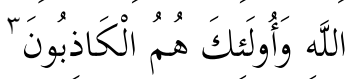

Artinya: Sebenarnya yang tergamak berdusta itu hanyalah orang-orang yang tidak beriman kepada ayat-ayat Allah, dan mereka itu ialah orangorang yang bertabikat berdusta.

Sudah sepatutnya kaum muslimin menjauhi berdusta, kerana dusta itu merupakan perbuatan orang-orang yang tidak beriman kepada Allah Subhanahu wata'ala. Pendusta merupakan salah satu dari perangainya orang-orang munafik, sebagaimana dalam hadits dalam shohihain dari hadits Abu Hurairoh beliau berkata Rosulullah s.a.w bersabda:

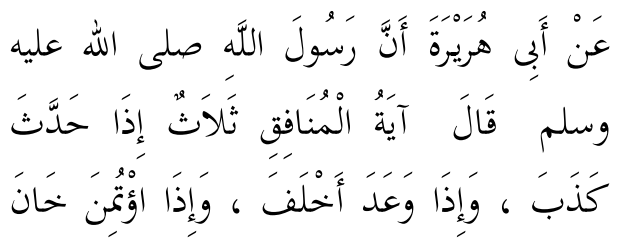

Artinya: Tanda orang munafik itu tiga perkara: apabila bercakap dia berdusta, apabila berjanji dia mengingkar janjinya, dan apabila dipertaruhkan amanah dia khianati.

\footnotetext{
${ }^{3}$ Al-Qur'an, an-Nahl,16:105

${ }^{4}$ Sahih Bukhari, juz 20:248, bab qaul yaayyuhallazina amanu, hadis no: 6095 , dan terdapat pada hadis no;33,2682, 2749, 1434 ${ }^{1}$, Hadis ini diriwayatkan oleh al-Bukhari, Muslim, at-Tirmizi, an-Nasa'I dari Abu Hurairah r.a.
}

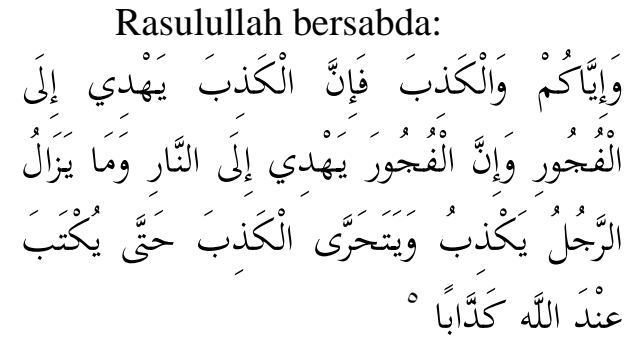

Artinya: Dan berhati-hatilah akan dusta kerana dusta membawa kepada kejelikan dan kejelikan membawa ke neraka, seseorang yang selalu berdusta maka akan ditulis di sisi Allah sebagai pendusta.

Dalam hadits yang mulia ini Rasulullah SAW menganjurkan umatnya untuk sentiasa jujur kerana akan menghantarkan ke dalam surga Allah SWT dan juga beliau memperingatkan untuk menjauhi kedustaan kerana ia akan menghantarkan pendusta ke dalam neraka Allah SWT dan apabila seseorang sentiasa melakukan kidhb, maka ia akan ditulis di sisi Allah SWT sebagai seorang yang pendusta.

\section{AKHLAK MAZMUMAH}

Di antara akhlak yang buruk adalah: berkata dusta

kesaksian yang dusta شَشَهَدَهُ الزُّور, annifaq, qazf, al-ifk, al-iftara, at-takzib, sebagai berikut:

\section{a. Bَوْلَ النُوْر}

Allah SWT menggandingkan berkata bohong dengan kesalahan syirik, firman Allah berikut:

\footnotetext{
${ }^{5}$ Sahih Muslim juz .13, h.16, bab qabih al-kadhab wa husnu al-shdq wa fadluh. Ulama tafsir yang menjelaskan hadis di atas terkait dengan surah at-Taubah/9:119, al-Ahzāb,33:35 sama ada Ibn Katsīr dalam kitabnya : tafsir alQur'an al-'Azhìm, dan as Suyuthiy dalam kitabnya ad-dar al-Manstur fi atta'wil bi alMa'tsur.
} 


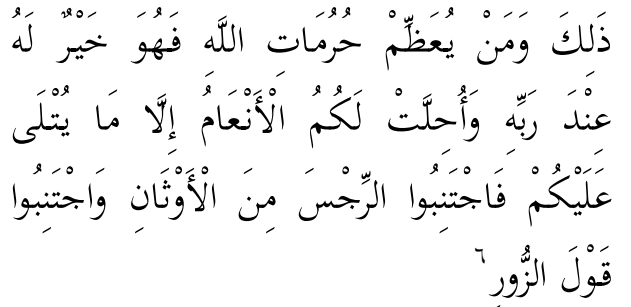

Artinya: Demikianlah (perintah Allah). Dan barangsiapa mengagungkan apaapa yang terhormat di sisi Allah maka itu adalah lebih baik baginya di sisi Tuhannya. Dan telah dihalalkan bagi kати sетиa binatang ternak, terkecuali yang diterangkan kepadamu keharamannya, maka jauhilah olehmu berhala-berhala yang najis itu dan jauhilah perkataan-perkataan dusta.

Ayat ini menekan berat tentang kesalahan berkata bohong kerana ia telah menggadingkannya dengan kesalaha syirik. Al-Imam Ahmad telah meriwayatkan sebuah hadith dengan sanadnya dari Fatik al-Asadi mengatakan : Rasulullah Saw. setelah mendirikan solat subuh dan apabila selesai dari solat itu beliau berdiri, seraya bersabda:

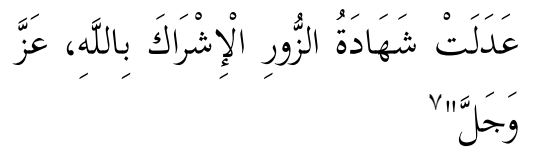

Artinya: Kesaksian yang dusta itu sama dengan mempersekutukan Allah SWT.

Kemudian baginda membacakan ayat Al-Hajj, 22:30. Allah mahu manusia meninggalkan segala bentu syikik dan menjauhi segala bentuk pembohongan, serta berdiri teguh di atas lunas kepercayaan tauhid yang benar dan bersih.

\footnotetext{
${ }^{6}$ Al-Qur' an, Hajj, 22:30

${ }^{7}$ Ahmad ibn Hanbal Abu Abdullah alsyaibani, Musnad al-Imam Ibn Hanbal, juz. 4, hal.231

${ }^{8}$ Sayyid Qutb,Fi Zilal al-Qur'an, 27:474
}

Di dalam kitab Sahihain telah disebutkan melalui riwayat $\mathrm{Abu}$ Bakrah, bahawa Rasulullah Saw. bersabda:

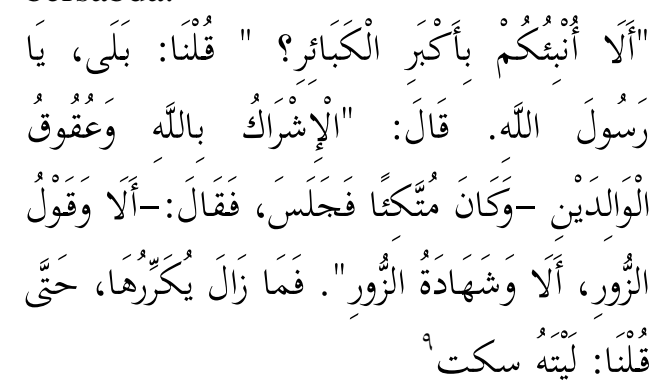

Artinya: "Ingat, saya akan memberitahu anda sekalian tentang dosa besar?" Kami (sahabat-sahabat) menjawab, "Sudah tentu kita akan, Wahai Rasulullah." Rasulullah bersabda, "Bersekutu dengan Allah dan menyakiti kedua ibu bapa," dia bersandar, kemudian duduk dan berkata, "Ingatlah, ingat, dan kesaksian palsu! "Nabi mengulangi ayat terakhir ini sehingga kami berkata (dalam diri kita).

\section{b. Munafik}

Allah telah menyebutkan perkataan an-nifāq dan kata jadiannya di dalam al-Qur'an sebanyak 37 kali dalam beberapa surah. Sifat nifak itu terbagi menjadi dua macam: Pertama: Nifaq I'tiqadi (nifak dalam bentuk keimanan) dan nifaq dalam bentuk amaliah, Nifak jenis I'tiqadi ini menyebabkan pelakunya keluar dari agama (millah). Orang seperti ini di dalam hatinya mendustakan kitab-kitab Allah dan para malaikat-Nya,

$$
\text { Perkataan nifaq }
$$
munafik bermaksud menampakkan (berpura-pura) keimanan dan

${ }^{9}$ Sahih Bukhari, jus 20:hal.63, hadis no 5976, juga terdapat pada hadis no 
menyembunyikan kekufuran.10Sifat munafik ada yang berkaitan dengan akidah; jenis ini menyebabkan pelakunya kelak di dalam neraka, dan ada yang berkaitan dengan perbuatan, jenis ini merupakan salah satu dari dosa besar. $^{11}$

Pendusta merupakan salah satu dari perangainya orang-orang munafik, sebagaimana dalam hadits dalam shohihain dari hadits Abu Hurairoh beliau berkata Rosulullah s.a.w bersabda:

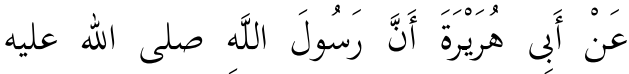

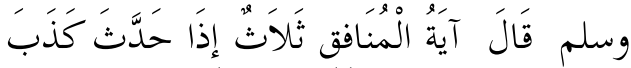

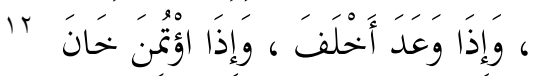

Artinya: Tanda orang munafik itu tiga perkara: apabila bercakap dia berdusta, apabila berjanji dia mengingkar janjinya, dan apabila dipertaruhkan amanah dia khianati.

Allah SWT. menceritakan kisah orang munafik, bagaimana mereka menyembunyikan kekufuran di dalam hati mereka dan mengumumkan keislaman dan pengakuan kepada Nabi s.a.w, Allah Swt. berfirman:

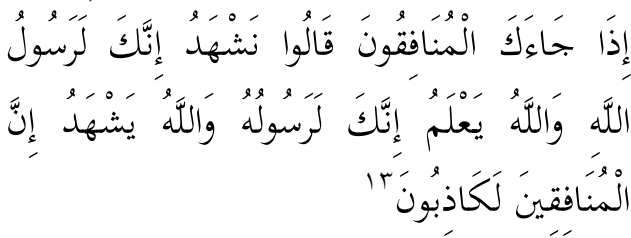

Artinya: Apabila orang-orang munafik datang kepadamu, mereka berkata:

${ }^{10} \mathrm{Ibn}$ 'Asyur, At-Tahrir wa at-Tanwir, juz.2:215, 'Azhim, , Ibn Kasir,Tafsir Al-Qur'an al-

${ }^{12}$ Sahih Bukhari, juz 20:248, bab qaul yaayyuhallazina amanu, hadis no: 6095 , dan terdapat pada hadis no;33,2682, 2749, 14341, Hadis ini diriwayatkan oleh al-Bukhari, Muslim, at-Tirmizi, an-Nasa'I dari Abu Hurairah r.a

${ }^{13}$ Al-Qur'an, al-Munafiqun, 63:1
"Kami mengakui, bahwa sesungguhnya kamu benar-benar Rasul Allah". Dan Allah mengetahui bahwa sesungguhnya kamu benar-benar Rasul-Nya; dan Allah mengetahui bahwa sesungguhnya orang-orang munafik itu benar-benar orang pendusta.

Al-quran menjelaskan ciri-ciri orang munafik adalah : Mengaku beriman, sesungguhnya mereka tidak meyakini kebenaran dari apa yang mereka ucapkan dalam hati mereka, mereka menggunakan sumpah-sumpah yang palsu sebagai perisai dan untuk berlindung, mereka menghalangi diri mereka sendiri dan orang ramai dari agama Allah. Kufur dan menukar hidayah dengan kesesatan. Mereka mempunyai penampilan yang baik, baik bercakap dan fasih. Apabila perkataan mereka didengar, maka pendengarnya akan terpesona oleh perkataan mereka yang berparamasastra, pengecut lagi penakut. bermusuh (kebenaran), ${ }^{14}$ Tabiat si munafik dijelaskan firman Allah SWT berikut:

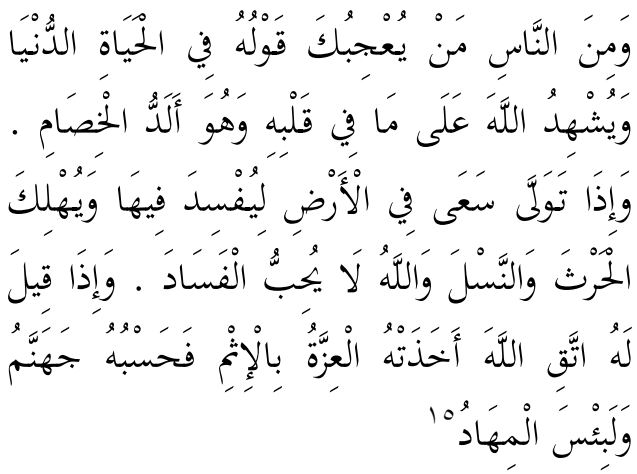

Artinya: Dan di antara manusia ada orang yang ucapannya tentang kehidupan dunia menarik hatimu, dan dipersaksikannya kepada Allah (atas

14 Ibn Kasir,Tafsir Al-Qur'an al'Azhim,8:131, Sayyid Qutb,Fi Zilal al-Qur'an, 7:211

${ }^{15}$ Al-Qur'an, al-Baqarah, 2:224 
kebenaran) isi hatinya, padahal ia adalah penantang yang paling keras. Dan apabila ia berpaling (dari kamu), ia berjalan di bumi untuk mengadakan kerusakan padanya, dan merusak tanam-tanaman dan binatang ternak, dan Allah tidak menyukai kebinasaan. Dan apabila dikatakan kepadanya: "Bertakwalah kepada Allah", bangkitlah kesombongannya yang menyebabkannya berbuat dosa. Maka cukuplah (balasannya) neraka Jahannam. Dan sungguh neraka Jahannam itu tempat tinggal yang seburuk-buruknya.

Berdasarkan ayat di atas dapat dipahami bahwa terdapat akhlak mazmumah di antaranya tipe hiprokit manusia yang berpura-pura, jahat dan pintar bercakap, ia mempperlihatkan dirinya sebagai tokoh yang amat penting dalam seluruh kegiatan kehidupannya. Rupanya menarik dan mengkagumi anda, tetapi budinya yang buruk menyakiti anda. apabila diseru kepada kebaikan dan bertaqwa kepada Allah SWT., ia tidak pernah kembali kepada kebenaran, dan tidak pernah mencoba membetulkan dirinya, malah ia terus dikongkong perasaan takabur untuk melakukan dosa. Dia merasa begitu sombong apabila diajak kepada kebenaran dan kebaikan, dan dia terus berusaha membinasakan tanaman dan kanak-kanak". 16

Makhluk (munafik) yang berbicara ini, dengan menggambarkan dirinya kepada anda sebagai seorang yang sangat baik, sangat ikhlas dan jujur, , sangat pengasih, bermaruah tinggi, sangat gemar member kebajikan, kebaktian, kebahagiaan dan

16 Sayyid Quthb, Tafsir Fi ZhilaliQur'an, Juz. 1.Hlm 612, kesucian kepada orang ramai. Inilah orang yang engkau kagumi tutur katanya. Kagumi kepetahan lidahnya, kagumi nada suaranya, dan kagumi pembicaraan-pembicaraannya tentang kebajikan," "(semua itu dilakukan) Demi menguatka kesan saranan dan untuk menekankan saranan keikhlasan dan kejujurannya dan seterusnya untuk menonjol-nonjolkan taqwa dan keikhlasannya kepada Allah, Jiwanya penuh dengan ghairah perseteruan dan permusuhan. Ia tidak menampakkan sebarang bayang kasih mesra dan perasaan samahan (toleransi). Ia tidak menunjukan sebarang ruang untuk kasih sayang dan kebajikan, untuk berbudi dan mementingkan kabajikan orang lain. ${ }^{17}$

Orang yang zahirnya bertentangan dengan batinnya, rupanya berlainan dengan budinya. inilah orang yang pintar berdusta, sehingga apabila tiba peranan bertindak terbukalah tembelang budinya yang tersembunyi, terterungkaplah segala akhlaknya yang tertutup dan terpampanglah hakikat kejahatannya, kezalimannya, hasad dengkinya, dan kerosakkan akhlaknya. ${ }^{18}$ Mereka yang mempunyai penyakit ini adalah orang-orang munafik, sedangkan penyakit tersebut adalah berupa keraguan yang merasuki hati mereka terhadap Islam. bertambah kekafiran mereka, kejahatan mereka di samping kejahatan yang ada dan kesesatan di samping kesesatan yang telah ada pada diri mereka ini merupakan pembalasan yang sesuai dengan jenis amal perbuatan, di samping kekafirannya yang telah ada disebabkan apa yang mereka dustakan kerana mereka mempunyai kedua sifat

\footnotetext{
${ }^{17}$ Op.cit., 1.Hlm. 615,

${ }^{18}$ Ibid.
} 
tersebut, yakni mereka adalah orangorang yang berdusta, juga mendustakan yang gaib. 19

Mengetahui orang munafik dijelaskan Allah SWT dalam firman yang lain:

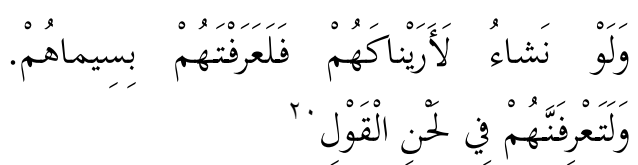

Artinya: Dan kalau Kami menghendaki, niscaya Kami tunjukkan mereka kepadamu sehingga kamu benar-benar dapat mengenal mereka melalui tanda-tandanya. Dan kamu benar-benar akan mengenal mereka dari kiasan-kiasan perkataan mereka.

Di antara mereka yang terkenal kemunafikannya ialah Abdullah ibnu Ubay ibnu Salul. Kemunafikannya telah disaksikan oleh Zaid ibnu Arqam r.a. setelah ada penjelasan mengenai sifat-sifat orang munafik. Sekalipun demikian, ketika Abdullah ibnu Ubay bin Salul mati, Nabi Saw. ikut menyalatkannya dan bahkan menyaksikan penguburannya, sebagaimana yang beliau lakukan terhadap kaum muslim lainnya. dan firman Allah SWT:

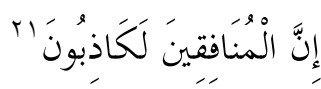

Artinya: sesungguhnya pengakuan mereka adalah dusta.

Pernyataan kaum Yahudi dan Nasrani tidak dapat diterima oleh kerana meraka tidak boleh mendatangkan bukti kebenaran dan dalil pada kitab suci Taurah dan Injil yang membenarkan ucapan mereka. Surah yang menjelaskan bahawa kaum

\footnotetext{
19 Ibn Kasir,Tafsir Al-Qur'an al'Azhim, , 1:179

${ }^{20}$ Al-Qur'an, Muhammad, : 30

${ }^{21}$ Al-Qir'an, Al-Munafiqun,63:1
}

Yahudi tidak sanggup mendatangkan hujjah ialah surah al-Baqarah, 2:94, Ali-'Imrān, 3:93,183, al-Jumu'ah.62:6. Bahkan Allah SWT membantah bahawa kaum Yahudi dan Nasara tidak wujud bukti benar perkataan mereka pada akiqah mereka, oleh itu mereka sebenarnya adalah munafik oleh sebab pendusta.

\section{c. Melempar tuduhan keji}

Melemparkan tuduhan zina kepada orang lain Qazaf yang baik lagi suci atau menafikan keturunannya. Jika sekiranya ia hanya menuduh seseorang lain mencuri, minum arak, murtad, termasuk juga mencaci yang boleh menjatuhkan maruah maka ia hanya di kenakan hukuman ta'zir. ${ }^{22}$ Menuduhkan tanpa mendatangkan empat orang saksi, dijelaskan firman Allah SWT:

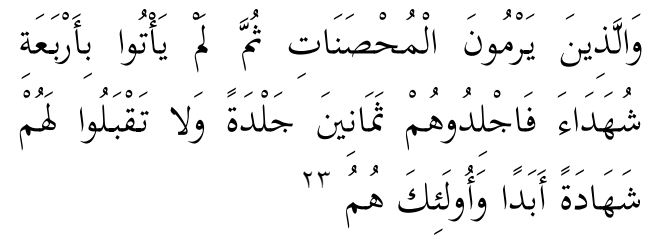

Artinya: Dan orang-orang yang menuduh wanita-wanita yang baik-baik (berbuat zina) dan mereka tidak mendatangkan empat orang saksi, maka deralah mereka (yang -menuduh itu) delapan puluh kali dera, dan janganlah kalian terima kesaksian mereka buat selama-lamanya. Dan mereka itulah orang-orang yang fasik,

Di dalam ayat ini diterangkan hukum dera bagi orang yang menuduh wanita yang baik-baik berbuat zina. Yang dimaksud dengan istilah muhsanah dalam ayat ini ialah wanita merdeka yang sudah balig lagi

\footnotetext{
${ }^{22}$ http://www.jais.gov.my /article/qazaftuduhan-zina, 2 Oktober 2017

${ }^{23}$ Al-Qur' an, An-Nur,24:4
} 
memelihara kehormatan dirinya. apabila yang dituduh melakukan zina itu adalah seorang lelaki yang terpelihara kehormatan dirinya, maka hukumnya sama, yakni si penuduh dikenai hukuman dera. Tiada seorang pun dari kalangan ulama yang memperselisihkan masalah hukum ini. Apabila si penuduh dapat membuktikan kebenaran dari persaksiannya, maka terhindarlah dirinya dari hukuman had (dan yang dikenai hukuman had adalah si tertuduhnya). ${ }^{24}$

Ada tiga macam sangsi hukuman yang ditimpakan kepada orang yang menuduh orang lain berbuat zina tanpa bukti yang membenarkan kesaksiannya, yaitu lapan puluh kali sebat, digugurkan kesaksiannya (tidak dipakai kesaksiannya) dan ia dicapkan sebagai seorang yang fasiq. Kemudian Allah SWT menyebutkan dalam firman selanjutnya:

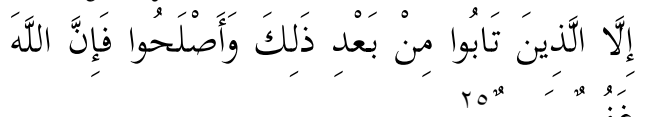
غفور رحيم

Artinya: kecuali orang-orang yang bertaubat sesudah itu dan memperbaiki (dirinya), maka sesungguhnya Allah Maha Pengampun lagi Maha Penyayang.

Para fuqaha telah berselisih tentang pengecualian ini, apakah pengecualian ini anya melibatkan hukum yang terakhir sahaja, iaitu dihapuskan sifat fasik darinya sahaja, sedangkan kesaksiannya terus kekal tidak diterima? Atau kesaksiannya juga boleh diterima apabila dia bertaubat?

\footnotetext{
${ }^{24}$ Ibn Kasir,Tafsir Al-Qur'an al'Azhim, . 6:13

${ }^{25}$ Al-Qir'an, An-Nur,24:5
}

Menurut Imam Malik, Imam Ahmad, dan Imam Syafii berpendapat bahawa apabila dia bertobat, maka kesaksiannya boleh diterima dan terhapuslah dirinya hukum fasiq. Tetapi ujar Imam Abu Hanifah: pengecualian itu hanya melibatkan ungkapan yang terakhir sahaja. Iaitu dihapuskah sifat fasiq sahaja dengan taubat itu, tetapi kesaksiannya terus ditolak. Asy-Sya'bi dan Ad-Dahhak mengatakan bahwa kesaksiannya tidak diterima, walaupun dia telah bertobat, kecuali dia membuat pengakuan terhadap dirinya bahawa dia telah membuat pembohongan dalam tuduhannya itu, ketika itu bolehlah diterima kesaksiannya. ${ }^{26}$

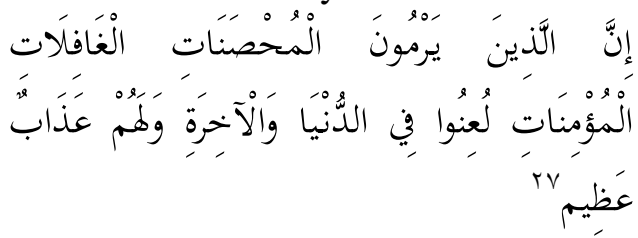

Artinya: Sesungguhnya orang-orang yang menuduh perempuan-perempuan yang terpelihara kehormatannya, yang tidak terlintas memikirkan sebarang kejahatan, lagi yang beriman, akan dilaknat (oleh Allah SWT) di dunia dan di akhirat dan, mereka pula akan beroleh azab seksa yang besar;

Ayat ini menggambarkan betapa besar dan kejinya jenayah yang dilakukan oleh mereka yang menuduh wanita muhsan ketika wanita-wanita itu dalam keadaan tidak berwaspada dan hati-hati dari kemungkinan tuduhan orang, sedangkan mereka mempunyai hati yang baik dan bersih, tenang dan yakin tidak takut kepada sesiapa kerana mereka tidak pernah

\footnotetext{
${ }^{26}$ Ibn Kat Sir, Sayyid Qutb,Fi Zilal alQur'an al-Qur'an, juz.18, hal.38

${ }^{27}$ Al-Qur' an, an-Nur,24:23
} 
melakukan kesalahan yang ditakuti mereka. $^{28}$

\section{d. Berdusta}

Perkataan al-Ifk bremaksud dusta dan bohong, ${ }^{29}$ mengubah sesuatu daripada bentuk asalnya, menunjukkan membalikan sesuatu, dan dikatakan membalikkan sesuatu apabia seseorang adalah dusta, ${ }^{30}$ terdapat pada firman Allah SWT:

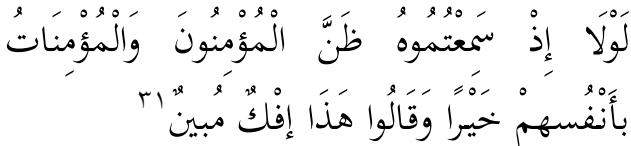

Artinya: Sepatutnya semasa kamú mendengar tuduhan itu, orang-orang yang beriman - lelaki dan perempuan, menaruh baik sangka kepada diri (orang-orang) mereka sendiri. dan berkata: "Ini ialah tuduhan dusta yang nyata".

firman Allah SWT yang berikut

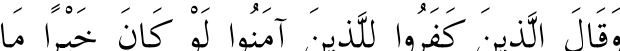
وقال الدين كفروا للذين آمنوا لو كان خيران مان

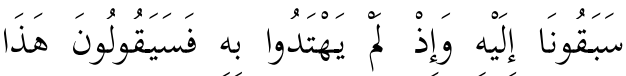
إفْلك قَّليكُ

Artinya: Dan orang-orang kafir berkata kepada orang-orang yang beriman: "Kalau sekiranya di (Al Quran) adalah suatu yang baik, tentulah mereka tiada mendahului kami (beriman) kepadanya. Dan kerana mereka tidak mendapat petunjuk dengannya maka mereka akan berkata: "Ini adalah dusta yang lama".

28 Sayyid Qutb,Fi Zilal al-Qur'an, juz.18:96

${ }^{29}$ Al-Munawwir, 31,

${ }^{30} \mathrm{Mu}$ 'jam al-Maqayis, 1:118

${ }^{31}$ Al-Qur'an, an-Najm, 53:11

${ }^{32}$ Al-Qur' an,al-Ahqaf,46:11
Tidaklah mereka berpendapat demikian, melainkan mereka mempunyai keyakinan bahawa diri mereka mempunyai kedudukan di mata Allah dan diperhatikan oleh-Nya. Mereka tersilap dalam kesalahan, bahawa semua perbuatan dan ucapan yang tidak terbukti berpunca dari para sahabat bererti hal itu adalah bid'ah. Kerana sesungguhnya tiada suatu perkara kebaikan pun yang mereka biarkan melainkan mereka (para sahabat) bersegera mengerjakannya Orang yang tidak beriman mengatakan bahawa segala apa yang terkandung di dalam Al-Qur'an adalah dusta dipetik dan orang dahulu kala. Mereka menafikan al-Qur'an dan orang-orang yang beriman kepadanya ${ }^{33}$

\section{e. Mengada-adakan bohong}

Perkataan ini maknanya mengadakan pembohonganpembohongan terhadap Allah, merekareka kata dusta, melakukan dosa, mengada-adakan sesuatu yang ajaib seperti sihir dan lainnya. Penjelasan mereka-reka perkataan dusta adalah seperti berikut:

Pada umumnya setelah perkataan ada perkataan dusta, di antaranya firman Allah SWT:

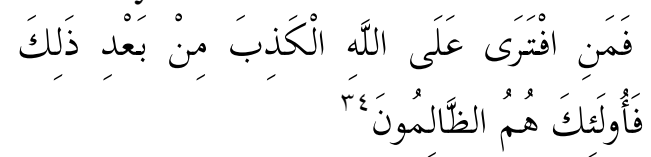

Artinya: (Jika tidak) maka sesiapa yang mereka-reka kata-kata dusta terhadap Allah sesudah yang demikian itu, maka mereka itulah orang-orang yang zalim.

Siapa yang menentang Allah SWT dan mengakui bahawa Allah

\footnotetext{
33 Ibn Kasir,Tafsir Al-Qur'an al'Azhim, ,

${ }^{34}$ Al-Qur'an, Ali-Imran,3:94
} 
SWT telah menetapkan untuk mereka pada hari Sabtu dan berpegang kepada Taurat selama-lamanya, bahawa Allah tidak menghantar seorang nabi lagi kepada Allah SWT dengan membawa bukti-bukti dan hujah-hujah selepas apa yang telah Kami jelaskan, iaitu kejadian nasakh, dan apa yang telah Kami sebutkan adalah nyata ${ }^{.35}$

Allah SWT menyifatkan orangorang munafik berbohong, kerana amalan, kata-kata dan tindakan mereka berlain dengan apa yang ada dalam hati nurani mereka, dan bertentangan dengan keyakinan dalam hati mereka, maka Munafiq ialah zahirya baik dan batinya jahat, dan ia termasuk sudut keyakinan amalan. Orang-orang munafik berupaya menipu mata pihak lain supaya terjerumus tanpa mereka sedari, ia akan mencari keuntungan duniawi sendiri dengan berusaha menutup-nutupi kepura-puraan mereka sehingga mereka terhindar dari hukuman yang semestinya mereka terima. Namun pada hakekatnya mereka adalah keliru, kerana yang mereka tipu hanyalah diri mereka sendiri, mereka tidak sedar. oleh kerana dihati mereka ada penyakit, misalnya iri terhadap Nabi. Dan dari penyakit ini justeru bertambahlah apabila kejahatan mereka semakin menjadi-jadi (seperti halnya satu pembohongan berusaha ditutup-tutupi dengan kebohongankebohongan. ${ }^{36}$

\section{f. $A l$-Takchīb melakukan kufur}

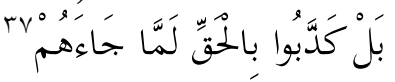

\footnotetext{
35 Ibn Kasir,Tafsir Al-Qur'an al'Azhim,

${ }^{36}$ Balil Abd al-Karim, al-Sidq dan alKidhb dalam al-Qur'an, 25 Mei 2011, www.alukah.net

${ }^{37}$ Al-Qur'an ,Qaf,50:5
}

Artinya: (Mereka tidak mahu berfikir betul) bahkan mereka (terburu-buru) mendustakan kebenaran apabila sahaja sampainya kepada mereka; oleh sebab itu, mereka berada dalam keadaan yang serba kacau.

Allah SWT dalam surah ArRahman (surat ke-55) ini mengulangulang firman-Nya, Maka nikmat Tuhan yang manakah (wahai jin dan manusia) yang hendak kamu dustakan? Pertanyaan ini sebenarnya untuk mengingatkan manusia tentang nikmatnikmat itu, di samping menimbulkan perasaan takut dan gentar serta celaan terhadap orang yang mengingkari nikmat-Nya. $^{38}$ di samping suatu pernyataan untuk mencatatkan pengakuan dan penyaksian, di mana dada seorang manusia dan jin yang mampu mendustakan nikmat-nikmat Allah di maqam seperti ini. ${ }^{39}$

Maka nikmat Tuhan yang manakah(wahai jin dan manusia) yang hendak kamu dustakan?, Pertanyaan tersebut terulang sebanyak tiga puluh satu kali. Lapan daripadanya disebut selepas diterangkan beberapa keajaiban ciptaan-Nya, selepas disebutkan perihal permulaan kejadian dan perihal "ma'ad" atau kembali ke akhirat, kemudian disebutkan sebanyak tujuh kali selepas diceritakan tentang azab neraka dan suasananya; sejajar dengan bilangan pintu neraka jahannam. Selepas itu disebutkan lapan kali selepas disifatkan syurga dan para penghuninya, ini sejajar dengan lapan bilangan pintu syurga. Sesiapa yang percaya kepada apan ayat yang awal, dam beramal dengan apa yang diwajibkan kepadanya, maka ia berhak

\footnotetext{
juz 27:208 27: 253
}

${ }^{38}$ Wahbah az-Zuhaili, Tafsir Al-Munir, 
mendapat daripada kedua-dua ganjaran lapan syurga itu daripada Allah, dan Allah selamatkan dia dari bencana tujuh perkara keburukan yang telah disebutkan dalam ayat terdahulu ${ }^{40}$

\section{g. Menuduh Keji Tanpa Bukti} Perkataan al-Qadzf berarti melempar, maksudnya melempar tuduhan zina kepada orang yang baikbaik tanpa mendatangkan saksi, maka perbuatan ini termasuk dosa besar, Kejahatan menuduh orang lain berbuat zina Hukum menuduh orang lain berbuat zina Menuduh berzina adalah dosa besar: 24:4, 24:23. Sanksi menuduh orang lain berbuat zinaMendera orang yang menuduh berzina: 24:4. Kesaksian penuduh zina tidak diterima: 24:4 Penuduh zina yang menyesal dan menarik kembali tuduhannya, Allah SWT berfirman:

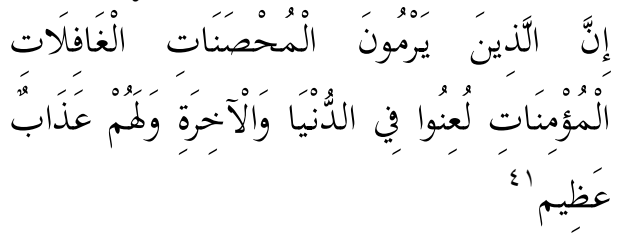

Artinya: Sesungguhnya orang-orang yang menuduh perempuan-perempuan yang terpelihara kehormatannya, yang tidak terlintas memikirkan sebarang kejahatan, lagi yang beriman, akan dilaknat (oleh Allah) di dunia dan di akhirat dan, mereka pula akan beroleh azab seksa yang besar;

Sesungguhnya orang-orang yang melemparkan tuduhan zina kepada wanita-wanita mukminat yang bersih, yang kecil kemungkinannya melakukan hal itu, bahkan karena kesibukannya berzikir kepada Allah SWT, mereka tidak sempat

40 Wahbah az-Zuhaili, Tafsir Al-Munir, juz 27:249.

${ }^{41}$ Al-Qur'an, an-Nūr, 24:23. memperhatikan hal-hal semacam itu-orang-orang itu akan dijauhkan dari kasih sayang Allah SWT di dunia dan di akhirat. Mereka akan mendapatkan siksa amat pedih jika mereka tidak segera bertobat. Orang yang menuduh tanpa ada saksi maka ia dikatakan fasik, dalam firman Allah SWT yang berikut:

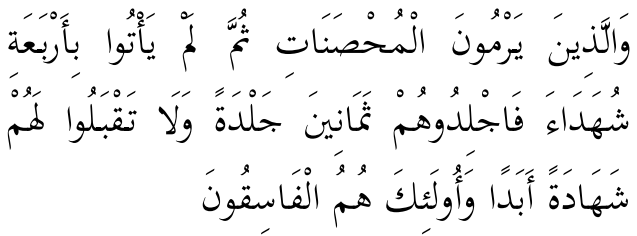

Artinya: Dan orang-orang yang melemparkan tuduhan (zina) kepada perempuan yang terpelihara kehormatannya, kemudian mereka tidak membawakan empat orang saksi, maka sebatlah mereka delapan puluh kali sebat; dan janganlah kamu menerima persaksian mereka itu selama-lamanya; kerana mereka adalah orang-orang yang fasik.

Seseorang yang menuduh orang lain menuduh orang lain berbuat zina harus dapat mendatangkan empat orang saksi yang memiliki kriteria muslim, dewasa, berakal sehat, adil lagi bebas dari tekanan. Kesaksian terhadap orang yang melakukan perzinaan dengan empat orang saksi dengan kriteria di atas ternyata belum cukup. Kepada keempat saksi tersebut disyaratkan bahawa dalam peristiwa dan waktu yang sama dan secara haqul yakin menyaksikan dengan mata kepalanya sendiri bagaimana perzinaan itu berlangsung secara jelas. ${ }^{43}$

Orang-orang yang melontarkan tuduhan zina kepada wanita-wanita yang menjaga kesuciannya tanpa dapat

${ }^{42}$ Al-Qur'an,an-Nūr, 24:4

43 Mustafa Kamal Pasha, Fikih Sunnah, Yogyakarta: Citra Karsa Mandiri, 2003), hal. 280-281 
mendatangkan empat orang saksi yang membenarkan tuduhannya, hukumannya adalah delapan puluh cambuk dan dengan tidak lagi menerima persaksian mereka atas perkara apa pun selamanya. Sebab, mereka memang pantas disebut sebagai orang-orang yang keluar dari batasbatas agama 44

\section{h. Al-Buht menuduh}

Perkataan al-buht البُهتان yang dimaksudkan dalam Al-Qur'an di antaranya bermakna kepalsuan dan pembohongan, kebingungan, al-buht pada surah al-Mumtahinah menyatakan bahawa kanak-kanak lelaki telah dinasabkan kepada yang bukan ibu bapanya oleh isteri-isteri, ini merupakan buht yang menghina, menyifatkan fitnah fitnah; iaitu: Isteriisteri menasabkan kepada suami mereka apa yang tidak mereka lakukan. ${ }^{45}$

al-buht lebih merbahaya dari pembohongan dan fitnah, kerana fitnah dan yang berkaitan kepada orang yang mengatakan perkara itu sendiri, tetapi al-buht berkenaan dengan orang lain, bekas tidak melebihi satu pembohongan, dan tangga kedua pada orang lain, jadi semua kepalsuan fitnah, tidak semua fitnah palsu. Tuduhan keji kepada orang baik-baik, firman Allah SWT yang berikut:

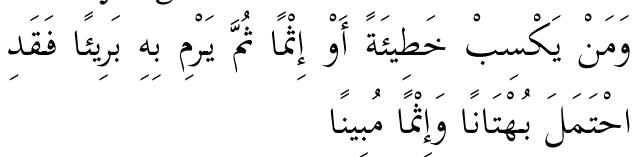

Artinya: Dan sesiapa yang melakukan suatu kesalahan atau suatu dosa, kemudian ia menuduhnya kepada orang yang tidak bersalah, maka

44 Qurais Shihab, Al-Misbah sihab, Qurais Shihab, Al-Misbah,

${ }^{45}$ Alusy, Ruh al-Ma'ani, 20:472

${ }^{46}$ Al-Qur'an, an-Nisa',4:112, sesungguhnya ia telah memikul kesalahan berbuat dusta, dan melakukan dosa yang amat nyata.

Sebagaimana tuduhan yang dilakukan Bani Ubairiq, tentang perilaku busuk mereka kepada laki-laki shalih yaitu Labid bin Sahl seperti pada hadits yang telah lalu, atau Zaid bin Samin orang Yahudi, menurut pendapat yang lainnya, padahal dia bebas atau bersih.Mereka adalah orangorang zhalim lagi penghianat seperti yang ditunjukkan oleh Allah kepada Rasul-Nya. Kemudian cacian dan celaan ini berlaku umum untuk mereka dan siapa pun selain mereka yang memiliki sifat seperti mereka, lalu melakukan tindakan kesalahan seperti mereka, maka mereka akan mendapatkan hukuman yang sama dengan mereka. ${ }^{47}$

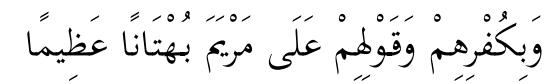

Artinya: Demikian juga (Kami laknatkan mereka) dangan sebab kekufuran mereka dan tuduhan mereka terhadap Maryam (dengan tuduhan yang amat dustanya.

Ali ibnu Abu Talhah meriwayatkan dari Ibnu Abbas, bahwa makna yang dimaksud ialah mereka menuduhnya berbuat zina. Hal yang sama dikatakan oleh As-Saddi, Juwaibir, Muhammad ibnu Ishaq, dan lain-lainnya. Pengertian ini jelas terbaca dari makna ayat, bahwa mereka memang menuduh Maryam dan putranya dengan tuduhan-tuduhan yang besar; mereka menuduh Maryam telah berbuat zina dengan seorang yang bernama Yusuf An Najjar, sehingga melahirkan Isa putra Maryam Tuduhan

\footnotetext{
47 Ibn Kasir,Tafsir Al-Qur'an al'Azhim, ${ }^{48}$ an-Nisa', 4:156
} 
itu sama sekali tidak benar,49 sebagaimana firman Allah SWT berikut:

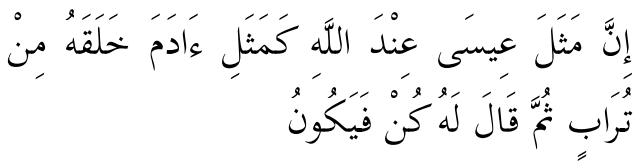

Artinya: Sesungguhnya perbandingan (kejadian) Nabi Isa di sisi Allah adalah sama seperti (kejadian) Nabi Adam. Allah telah menciptakan Adam dari tanah lalu berfirman kepadanya: "Jadilah engkau!" maka menjadilah ia.

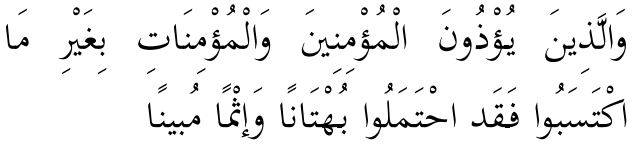

Artinya: Dan orang-orang yang mengganggu serta menyakiti orangorang lelaki yang beriman dan orangorang perempuan yang beriman dengan perkataan atau perbuatan yang tidak tepat dengan sesuatu kesalahan yang dilakukannya, maka sesungguhnya mereka telah memikul kesalahan menuduh secara dusta, dan berbuat dosa yang amat nyata.

Menurut Abdullah bin Abbas r.a ayat ini diturunkan berkenaan dengan tuduhan Abdullah bin Ubai terhadap Siti 'aisyah yang dituduh berbuat krisis moral dalam perjalanan pulang beserta Nabi Muhammad saw setelah memerangi Bani Mustaliq, yang terkenal dengan hadisul ifki. Dan menurut Abu Hurairah Rasulullah saw pernah ditanya tentang apa ertinya bergaul bebas. Beliau menjawab: "Engkau menyebut-nyebut saudaramu dengan sesuatu yang dibencinya". Nabi ditanya lagi: "Bagaimana jika yang disebut itu memang benar terdapat suatu kenyataan?". Nabi menjawab:

\footnotetext{
${ }^{49}$ Ibn Kasir,Tafsir Al-Qur'an al'Azhim,

${ }^{50}$ Al-Qur' an, Ali-Imran, 3:59

${ }^{51}$ Al-Qur' an, al-Ahzab,33:58,
}

"Bila yang diucapkan itu benar engkau telah mengumpat kepadanya, dan bila itu tidak benar maka engkau telah membuat kedustaan terhadapnya". Dan menurut riwayat 'Aisyah r.a bahawa Nabi saw pernah ditanya:" Riba manakah yang paling berat di sisi Allah, beliau bersabda menghalalkan kehormatan seorang manusia, lalu Nabi membacakan ayat ini. ${ }^{52}$

Semestinya, ketika sahabat mendengar berita bohong itu, kalian menasihati mereka agar tidak melakukan tuduhan karena hal itu tidak pantas buat kalian. Semestinya pula sahabat heran terhadap kebohongan yang sangat hina dan berbahaya yang mereka perbuat itu. Di Madinah waktu itu terdapat sekumpulan manusia yang mengaturkan rancangan-rancangan jahat terhadap orang beriman lelaki dan perempuan dengan menyebarkan fitnah-fitnah yang keji terhadap mereka, merancangkan perkataanperkataan jahat yang menghebohkan berbaga-bagai tuduhan dusta terhadap mereka. ${ }^{53}$ Hal yang sama telah diriwayatkan oleh Imam Turmuzi, dari Qutaibah, dari Ad-arawardi, kemudian Imam Turmuzi mengatakan bahwa hadis ini hasan sahih:.

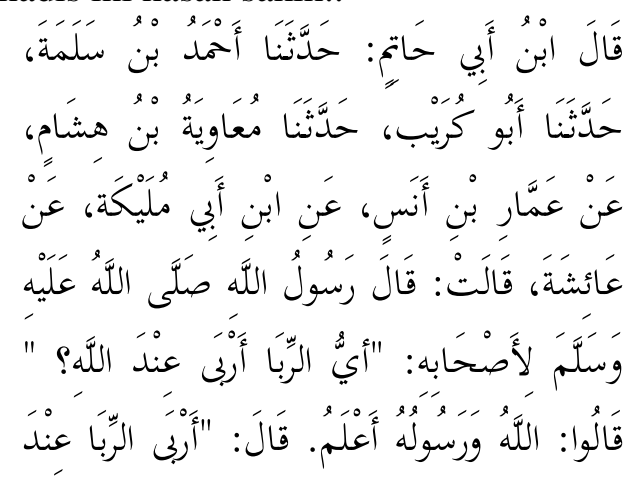

\footnotetext{
52 Departemen Agama Repulik Indonesia, Tafsir Al-Qur'a, al-Karim, 53 Sayyid Qutb, ,Fi Zilal al-Qur'an, $5: 257$
} 


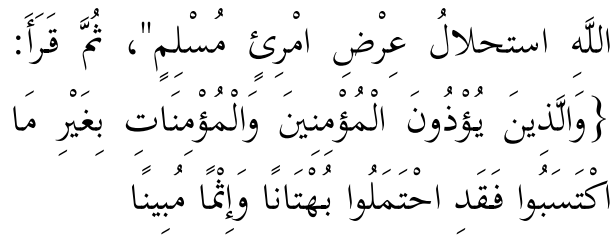

Artinya: Ibnu Abu Hatim mengatakan, telah menceritakan kepada kami Ahmad ibnu Salamah, telah menceritakan kepada kami Abu Kuraib, telah menceritakan kepada kami Mu'awiyah ibnu Hisyam, dari Ammar ibnu Anas, dari Ibnu Abu Mulaikah, dari Aisyah yang mengatakan bahwa Rasulullah Saw. pernah bersabda kepada para sahabatnya: "Riba apakah yang paling parah di sisi Allah?" Mereka menjawab, "Allah dan Rasul-Nya lebih mengetahui." Rasulullah Saw. bersabda, "Riba yang paling berat di sisi Allah ialah menghalalkan kehormatan seorang muslim." Kemudian Nabi Saw. membacakan firman Allah Swt.: Dan orang-orang yang menyakiti orang-orang yang mukmin dan mukminat tanpa kesalahan yang mereka perbuat, maka sesungguhnya mereka telah memikul kebohongan dan dosa yang nyata. (AlAhzab: 58)

Menuduh dengan batil kepada orang lain sesuatu yang tidak layak begi mereka adalah dusta yang diadaadakan, dengan tujuan menyakiti, adalah dusta yang lebih buruk. Untuk menjatuhkan merwah kaum muslimin, al-buht juga dapat merusak hubungan antara sesama manusia, individu dengan keumpulan masyarakat, bahkan dapat merusakkan perhubungan antar bangsa dan Negara.

\section{Kesimpulan}

1. Akhlak merupakan cerminan dari keyakinan yang wujud pada perilaku kehidupan seharian, dalam bermasyarakat berbangsa dan bernegara.

2. di antaranya adalah akhlak mazmumah adalah akhlak buruk termasuk dusta, sesama manusia, al-kidhb seperti : berbohong, berpura-pura jujur (munafik), menuduhan orang baik-baik berbuat keji tanpa ada bukti.semua perbuatan di atas dimurkai Allah SWT dengan berbagai konsekwensinya di dunia dan di akhirat dan bahkan juga dibenci oleh sesame manusia.

3. Dusta membawa kepada kedurhakaan, sedangkan kedurhakaan itu membawa kepada neraka.

4. Dusta juga termasuk ciriciri seorang munafik, sikap seperti ini mesti dijauhi dan di cegah orang lain melakukannya.

\section{Daftar Kepustakaan}

Alusiy, syihabuddin mhd ibn Abdullah al-Husainiy, Ruhu al-Ma'aniy $f i$ tafsir al-Qur'an al-'Azhim wa sab'u al-Matsaniy, Muassasah ar-Risalah,2000,

Al-Biqai, Burhanudddin Abi al-Hasan Ibrahim bin Umar, Nizam adDurar fi Tanasub al-Ayah wa as-Suwar, juz.7, hal.605

Al-Bukhary, Muhammad bin Ismail bin Ibrahim bin alMughirah,al-Jami as-Sahih al-Musnad min hadis Rasulullah saw wasunnatih wa ayatih SahihBukhari, juz. 1. Hal.58, 
Al-Husaini, Mohammed Rashid bin Ali Ridha bin Mohammed Shams alDin bin Muhammad Bahauddin maula Ali bin Khalifa Kulmuny, Tafsir al-Qur'an al-Hakim (Tafsir al-Manar), Kairo, AlHaiah al-Mishriyah al-Ammah lil kitab, 1990

Al-Maraghi, Ahmad bin Mustafa, Tafsir al-Maraghi, Mesir, Darul Fikri, 1970

Al-Qurthubi, Abu Abdullah bin Muhammad bi Ahmad bin Abi Bakr bin Farah al-Anshari alKhuzraji Syamsuddi, Al-Jami' al-Ahkam al-Qur'an ,Tafsir AlQurthubi, Kairo; Dar al-Kutb alNishriyah, 1994

Al-Qusyairiy, Abd al-Karim bin Hawzan bin Abd al-Malik, Lithaif al-Isyarah, Tafsir alQusyairy, Mesir:Al-Haiah alMisriyah al-Amah lilkitab, 1999

Al-Sa'di, Abdurrahman bin Nasir bin Abdullah, Taisir al-Karim arRahman fi tafsir kalam alMannan, Muassasah ar-Risalah, 2000

Shihab, M Quraish,Tafsir al-Misbah Pesan Kesan dan keserasian alQuran, Tanggaerang: Lentera Hati,cet III,2005

Al-Thabariy, Muhammad bin Jarir bin Yazid bin Katsir ibn Ghalib alAmaliy Abu Ja'far, Jami' alBayan fi takwil al-Qur'an, 2:356,

Al-Wahidi, Abu al-Hasan bin Ahmad, Al-Washit fi Tafsir al-Quran, Dar al-Kutut al-Ilmiyah, Beirut. 1994.

Qutb, Sayyid, Fi Zilal al-Qur'an, Beirut, Dar el-Fikr, 1971

Al-Zuhaili, Wahba bin al-Mustafa, Tafsir Al-Munir fi 'Aqidah wa
as-Syari'ah wa al-Manhaj

Beirut, Dar Elfikri,1991 